\title{
FORMULATION AND EVALUATION OF NOVEL FLOATING IN SITU GELLING SYSTEM OF MACROLIDE ANTIBIOTIC USING DIFFERENT GELLING POLYMERS
}

\author{
Jahangir Mohammed Asadullah ${ }^{1}$, Dr. Saleem MA ${ }^{1^{*}}$, Shahab Mohammed Shadab ${ }^{2}$, Muheem Abdul ${ }^{3}$, Saleem \\ Shakir ${ }^{4}$
}

${ }^{\mathbf{1}}$ Department of Pharmaceutics, Luqman College of Pharmacy, Gulbarga, Karnataka, India-585102

${ }^{2}$ Department of Pharmaceutics, Luqman College of Pharmacy, Gulbarga, Karnataka, India-585102

${ }^{3}$ Department of Pharmaceutics, Jamia Hamdard, New Delhi, India-110019

${ }^{4}$ Department of Pharmacology, Luqman College of Pharmacy, Gulbarga, Karnataka, India-585102

Received 04 Aug 2015; Review Completed 25 Aug 2015; Accepted 26 August 2015, Available online 15 Sep 2015

\begin{abstract}
:
Floating drug delivery system comes with the advantage of sustained release of drugs over a prolonged period of time thereby maximising the oral absorption of drugs with narrow absorption window, thus, it overcomes the challenges of conventional oral drug delivery system. In situ gelling system is a novel approach towards this. The aim of the present work was to develop a novel floating in situ gelling system for sustained drug delivery of Azithromycin dihydrate for eradication of $H$. pylori. In situ gelling system were prepared by dissolving different concentrations of gelling polymers like sodium alginate, xanthan gum, gellan gum in deionized water at $80^{\circ} \mathrm{C}$. After cooling to $40^{\circ} \mathrm{C}$ fixed amount of drug and calcium carbonate were dispersed in it with continuous stirring. Compatibility between drug and polymers were confirmed by FTIR studies. All formulations showed $\mathrm{pH}$ in the range of 6.4 to 6.9 , drug content was found to be in the range of $97.29 \%$ to $99.27 \%$, floating lag time was less than 1 min, duration of floating was more than $24 \mathrm{~h}$ for all the prepared formulations. It was observed that the gelling capacity, viscosity and water uptake by the gel increased with the increase in polymer concentration. In vitro drug release was found to be in between $82.11 \%$ to $89.49 \%$, up to $8 \mathrm{~h}$, and the maximum drug release was shown by formulation F1. Drug release responded inversely with the increase in polymer concentration. The release kinetics of all the formulations followed Higuchi diffusion mechanism. Hence, a floating in situ gelling system of Azithromycin dihydrate could be prepared using different concentrations of gelling polymers to increase the patient compliance with reduced dosing frequency and increased residence time of drug in the stomach for better eradication of $H$. pylori.
\end{abstract}

Keywords: Floating drug delivery system, Azithromycin dihydrate, H. pylori, In situ gelling system.

\section{INTRODUCTION:}

Helicobacter pylori, one of the most common bacteria, and are capable of colonizing the hostile environment of the human stomach and are capable of causing peptic ulcers. There are other micro organisms which can cause serious stomach specific infections, namely Klebsiella, Salmonella, some harmful strains of E.coli, Streptococcus etc ${ }^{1}$. Many antibacterial agents have been used to treat infections caused by above pathogens, but different studies reveals that eradication of such bacterium are not efficient due to some basic hindrance like instability of drug in low $\mathrm{pH}$ of the gastric fluid, very low concentration of drug reaching the bacteria under the mucosa, short residence time of the antibiotic in the stomach ${ }^{2}$. Patient compliance, side effect and bacterial resistance falls under the secondary problems for the same. One approach for effective eradication of H. pylori and other pathogens is to deliver the antibiotic locally in the stomach with better stability and longer residence time, which will allow more of the active drug to penetrate through the gastric mucus layer to act on infectious organism ${ }^{3}$.

Floating drug delivery system (FDDS) is a novel approach to achieve gastric retention to obtain sufficient drug bioavailability. Due to less bulk density than gastric fluids, these systems are capable of maintaining their buoyancy in the stomach for a prolonged period of time, thus with a desired rate drug is released slowly in the stomach. After the drug is released, the residual system is emptied from the stomach ${ }^{4}$.

*For Correspondence: Dr. Saleem MA, HOD, Department of Pharmaceutics, Luqman College of Pharmacy, Gulbarga, Karnataka, India-585102,

Email: ssaleempharm@ rediffmail.com 
In situ gelling system is a novel approach in the FDDS. In situ gels which when administered are in solution form, but as it comes in contact with gastric fluids, it forms gels. The phase transition of in situ gels may be attributed to one or combination of different stimuli like ionic interaction/pH change/ temperature modulation and solvent exchange 5 . In situ gelling systems come with the advantages of ease of administration, reduced frequency of administration, improved patient compliance and comfort ${ }^{6}$. As the gelling capacity of the in situ gels increases, their residence time in the stomach increases which eventually leads sustains the delivery of the drug.

Azithromycin dihydrate is a macrolide antibiotic used in the treatment of many gram negative and gram positive infections. It is chosen as the active drug in the present study to be incorporated in the in situ gelling system due to its low bioavailability following oral administration $^{7}$; their tablet form shows low bioavailability around $34 \pm 19 \%$ and their stability in the gastric environment. Since, with a low oral bioavailability they are needed to be taken for several days to completely eradicate the infection. But the novel floating in situ gelling system of Azithromycin dihydrate will come with the advantage of increased gastric residence time, which eventually will result in prolonged drug delivery with better patient compliance and lesser dosing frequency.

\section{MATERIALS AND METHOD:}

Azithromycin dihydrate was obtained as a gift sample from Glow Pharma. Gellan gum was purchased from Rajesh chemical co. Mumbai. All other materials used were of analytical grade.

\section{Preparation of in situ gelling system:}

Sodium alginate, xanthan gum and gellan gum solutions of different concentrations (1.0-2.0 \% w/v) were prepared in deionized water containing sodium citrate $(0.45 \% \mathrm{w} / \mathrm{v})$. The Sodium alginate, Xanthan gum and Gellan gum were dispersed in deionized water, heated to $60^{\circ} \mathrm{C}$ to $90^{\circ} \mathrm{C}$ with stirring and then cooled below to $40^{\circ} \mathrm{C}$. Fixed quantity of drug $(250 \mathrm{mg})$ and calcium carbonate $(0.05 \% \mathrm{w} / \mathrm{v})$ was added after cooling the solution below $40^{\circ} \mathrm{C}$ with continuous stirring to form uniform dispersion. These prepared sols were stored at room temperature until further use.

\section{Evaluation:}

\section{Compatibility studies:}

The drug polymer interaction studies were carried by FTIR technique by $\mathrm{KBr}$ pelletization method. The physical mixture of drug and polymers were taken in a ratio of $1: 1$ and mixed uniformly with demoisturized $\mathrm{KBr}^{8}$. The mixture was then compressed to a thin transparent pellet by subjecting to hydraulic press, which is then placed in the path of IR rays using a sample holder to record the spectra from $400-4000 \mathrm{~cm}^{-}$ 1 .

\section{In vitro gelation study ${ }^{9}$ :}

The in vitro gelling capacity of prepared formulations was measured by placing $5 \mathrm{ml}$ of the gelation solution
$(0.1 \mathrm{~N} \mathrm{HCl}, \mathrm{pH} 1.2)$ in a $15 \mathrm{ml}$ borosilicate glass test tube and maintained at $37 \pm 1{ }^{0} \mathrm{C}$ temperature. $1 \mathrm{ml}$ of formulation solution was added with the help of pipette. The formulation was transferred in such a way that places the pipette at surface of fluid in test tube and formulation was slowly released from the pipette. As the solution comes in contact with gelation solution, it was immediately converted into stiff gel like structure; the gelling capacity of solution was evaluated in the basis of stiffness of formed gel and time period for which the formed gel remains as such. The in vitro gelling capacity was graded in three categories on the basis of gelation time and time period for which the formed gel remains.

(+) Gels after few minutes, dispersed rapidly.

(++) Gelation immediately remains for few hours.

$(+++)$ Gelation immediate remains for an extended period.

\section{In vitro floating studies ${ }^{10}$ :}

The in vitro floating study was determined using USP dissolution apparatus having $500 \mathrm{ml}$ of simulated gastric fluid (pH 1.2). The Petri dish containing $5 \mathrm{ml}$ of in situ gelling solution was immersed into dissolution apparatus (USP24) containing $500 \mathrm{ml}$ of SGF (pH 1.2) at $37{ }^{\circ} \mathrm{C}$. The time the formulation took to emerge on the medium surface (floating lag time) and the time the formulation constantly floated on the dissolution medium surface (duration of floating) were noted by visual observation.

\section{Determination of viscosity ${ }^{9,11}$ :}

Viscosity of the samples was determined using a Brookfield digital viscometer with spindle number 2 . The sample temperature was controlled at $25 \pm 1{ }^{0} \mathrm{C}$ before each measurement. Viscosities of gels were determined at different shear rates from 10 to $100 \mathrm{rpm}$ at room temperature.

\section{Drug Content ${ }^{12}$ :}

$5 \mathrm{ml}$ of the solution was added to $900 \mathrm{ml}$ of simulated gastric fluid $(0.1 \mathrm{~mol} / \mathrm{l} \mathrm{HCl}, \mathrm{pH} 1.2)$ and stirred for $1 \mathrm{hr}$ on a magnetic stirrer. The solution was filtered, suitably diluted with simulated gastric fluid and the drug concentration was determined by using a UV-visible spectrophotometer at $272 \mathrm{~nm}$ against a suitable blank solution.

\section{Measurement of water uptake by the gel $^{13,14}$ :}

The water uptake by the gel of all formulations can be determined using a thermo-gravimetric analyzer. But in this present study a simple method has been adopted to determine the water uptake by the gel. The in situ gel formed in $40 \mathrm{ml}$ of gastric acid buffer $(\mathrm{pH}$ 1.2) was used for this study. From each formulation the gel portion from the buffer was separated and the excess buffer was blotted out with a tissue paper. The initial weight of the gel taken was weighed and to this gel 10 $\mathrm{ml}$ of distilled water was added and after every $30 \mathrm{mins}$ of the interval water was decanted and the weight of the gel was recorded and the difference in the weight was calculated and reported. 


\section{Microbiological studies:}

Four petridish were prepared with nutrient agar medium using micro pipette, $0.2 \mathrm{ml}$ of seeded broth containing test organism were spreaded uniformly. With an aluminium bore of $5 \mathrm{~mm}$ diameter four wells were cut out on the agar media. Each well was filled with equal quantity of test and standard alternatively and in a zig zag manner. The plates were then incubated at $37 \pm 1{ }^{0} \mathrm{C}$ for $24 \mathrm{~h}$. After the incubation period the mean diameter of zone of inhibition in $\mathrm{cm}$ obtained around the well were measured. Strict aseptic conditions were followed for the entire process ${ }^{15}$.

\section{In vitro drug Release $^{16}$ :}

The release of Azithromycin dihydrate was studied using USP type II dissolution apparatus containing 500 $\mathrm{ml}$ of $0.1 \mathrm{~N} \mathrm{HCl}$ maintained at $37 \pm 0.5^{\circ} \mathrm{C}$ and stirred at $50 \mathrm{rpm}$. Samples were collected periodically and replaced with a fresh dissolution medium. These samples were analyzed for the drug present in them with help of UV spectrophotometer at $215 \mathrm{~nm}$. Further the in vitro drug release for the drug release kinetics like zero order (cumulative \%drug release against time), first order release (log cumulative \%drug release against time), Higuchi equation (cumulative \%drug release against square root of time and Korsmeyer peppas model (log cumulative \%drug release against log time) were also studied.

\section{RESULTS AND DISCUSSION:}

The composition of various formulations of Azithromycin dihydrate floating in situ gels were shown in table 1.

The identification characterization of Azithromycin dihydrate and compatibility with different polymers were carried out using infrared spectroscopy from 400 to $4000 \mathrm{~cm}^{-1}$ using $\mathrm{KBr}$ pellets. As there were no major changes in the peaks, indicates that there was no incompatibility of the drug with the polymers used in the formulations fig 1 .

Table 1: Formulation table of Azithromycin dihydrate in situ gelling system

\begin{tabular}{|c|c|c|c|c|c|c|c|c|c|}
\hline Ingredients & F1 & F2 & F3 & F4 & F5 & F6 & F7 & F8 & F9 \\
\hline $\begin{array}{c}\text { Azithromycin } \\
\text { dihydrate }\end{array}$ & $\begin{array}{l}250 \\
\mathrm{mg}\end{array}$ & $\begin{array}{l}250 \\
\mathrm{mg}\end{array}$ & $\begin{array}{l}250 \\
\mathrm{mg}\end{array}$ & $\begin{array}{c}250 \\
\mathrm{mg}\end{array}$ & $\begin{array}{c}250 \\
\mathrm{mg}\end{array}$ & $\begin{array}{c}250 \\
\mathrm{mg}\end{array}$ & $\begin{array}{l}250 \\
\mathrm{mg}\end{array}$ & $\begin{array}{c}250 \\
\mathrm{mg}\end{array}$ & $\begin{array}{c}250 \\
\mathrm{mg}\end{array}$ \\
\hline Sodium Alginate & $\begin{array}{l}1.0 \% \\
\mathrm{w} / \mathrm{v}\end{array}$ & $\begin{array}{l}1.5 \% \\
w / v\end{array}$ & $\begin{array}{c}2.0 \% \\
\mathrm{w} / \mathrm{v}\end{array}$ & - & - & - & - & - & - \\
\hline Gellan gum & - & - & - & $\begin{array}{l}1.0 \% \\
\mathrm{w} / \mathrm{v}\end{array}$ & $\begin{array}{c}1.5 \% \\
\mathrm{w} / \mathrm{v}\end{array}$ & $\begin{array}{c}2.0 \% \\
\mathrm{w} / \mathrm{V}\end{array}$ & - & - & - \\
\hline Xanthan gum & - & - & - & - & - & - & $\begin{array}{l}1.0 \% \\
\mathrm{w} / \mathrm{v} \\
\end{array}$ & $\begin{array}{l}1.5 \% \\
\mathrm{w} / \mathrm{v} \\
\end{array}$ & $\begin{array}{c}2.0 \% \\
\mathrm{w} / \mathrm{v}\end{array}$ \\
\hline Sodium Citrate & $\begin{array}{l}0.45 \% \\
w / v\end{array}$ & $\begin{array}{l}0.45 \% \\
w / v\end{array}$ & $\begin{array}{l}0.45 \% \\
w / v\end{array}$ & $\begin{array}{l}0.45 \% \\
w / v\end{array}$ & $\begin{array}{l}0.45 \% \\
w / v\end{array}$ & $\begin{array}{l}0.45 \% \\
w / v\end{array}$ & $\begin{array}{l}0.45 \% \\
w / v\end{array}$ & $\begin{array}{c}0.45 \% \\
\mathrm{w} / \mathrm{v}\end{array}$ & $\begin{array}{c}0.45 \% \\
w / v\end{array}$ \\
\hline $\begin{array}{c}\text { Calcium } \\
\text { Carbonate }\end{array}$ & $\begin{array}{c}0.50 \% \\
\mathrm{w} / \mathrm{v}\end{array}$ & $\begin{array}{c}0.50 \% \\
\mathrm{w} / \mathrm{v}\end{array}$ & $\begin{array}{c}0.50 \% \\
\mathrm{w} / \mathrm{v}\end{array}$ & $\begin{array}{c}0.50 \% \\
\mathrm{w} / \mathrm{v}\end{array}$ & $\begin{array}{c}0.50 \% \\
\mathrm{w} / \mathrm{v}\end{array}$ & $\begin{array}{c}0.50 \% \\
\mathrm{w} / \mathrm{v}\end{array}$ & $\begin{array}{c}0.50 \% \\
\mathrm{w} / \mathrm{v}\end{array}$ & $\begin{array}{c}0.50 \% \\
\mathrm{w} / \mathrm{v}\end{array}$ & $\begin{array}{c}0.50 \% \\
\mathrm{w} / \mathrm{v}\end{array}$ \\
\hline Water (q.s) & $10 \mathrm{ml}$ & $10 \mathrm{ml}$ & $10 \mathrm{ml}$ & $10 \mathrm{ml}$ & $10 \mathrm{ml}$ & $10 \mathrm{ml}$ & $10 \mathrm{ml}$ & $10 \mathrm{ml}$ & $10 \mathrm{ml}$ \\
\hline
\end{tabular}




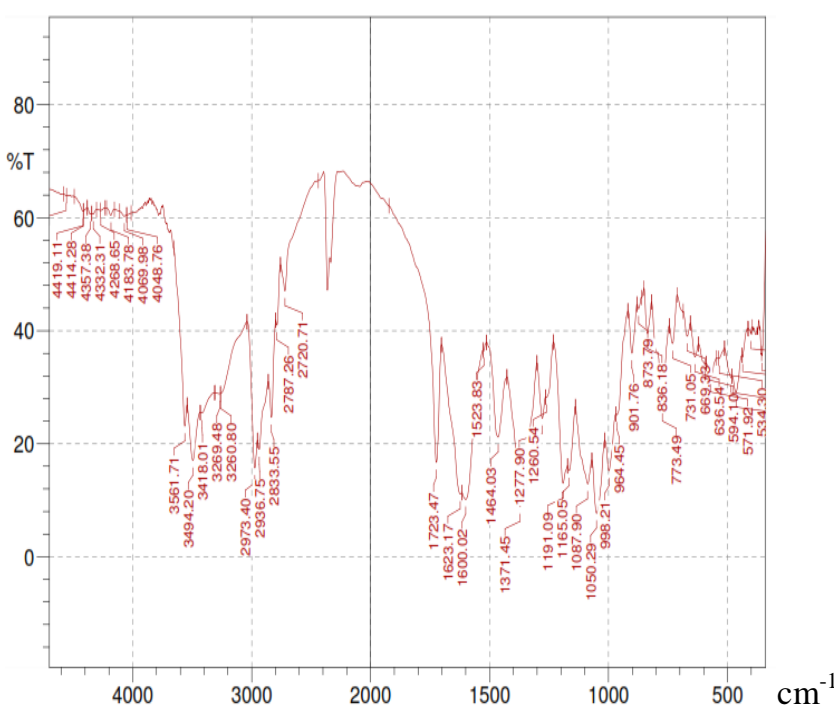

(1)

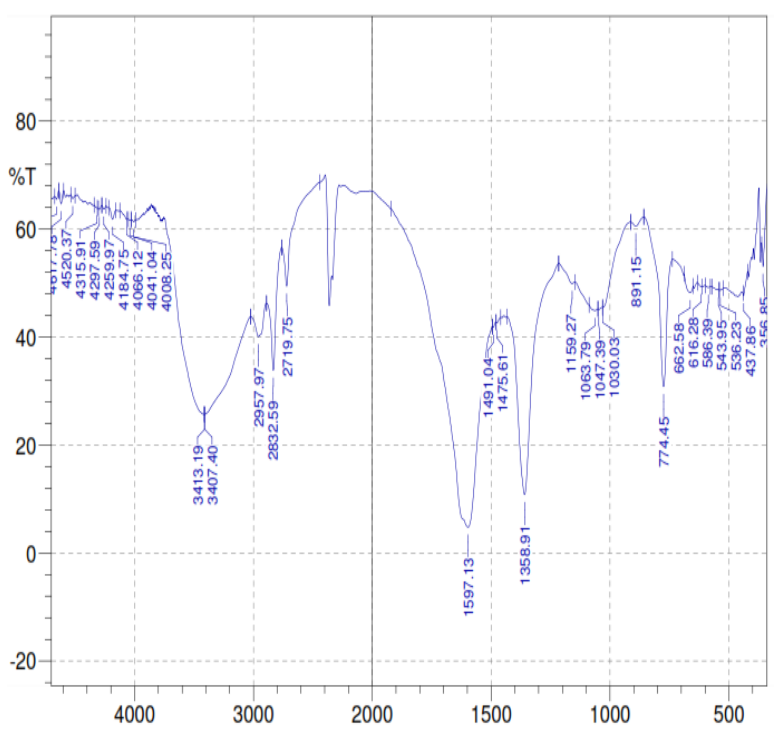

(3)

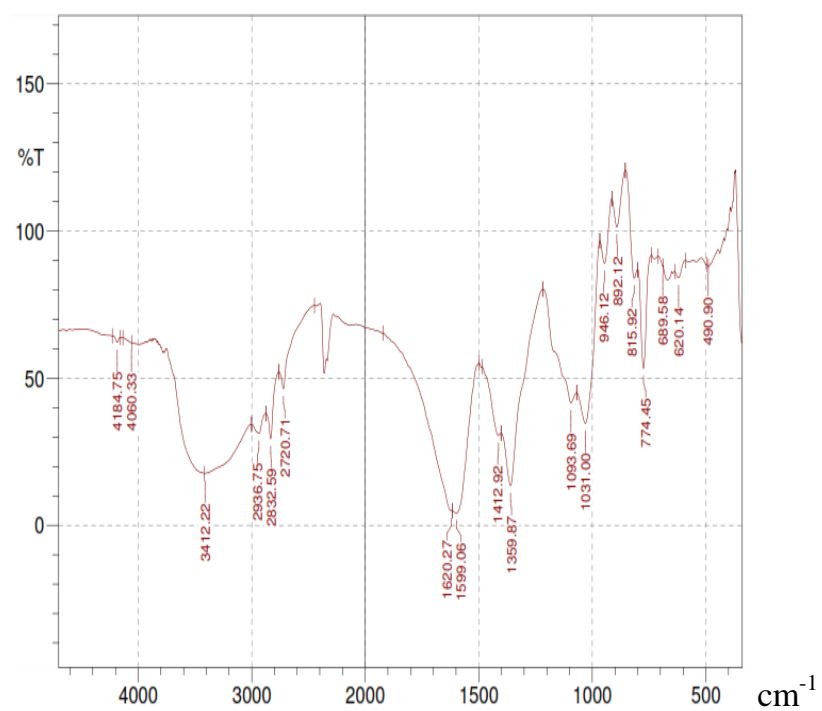

(2)

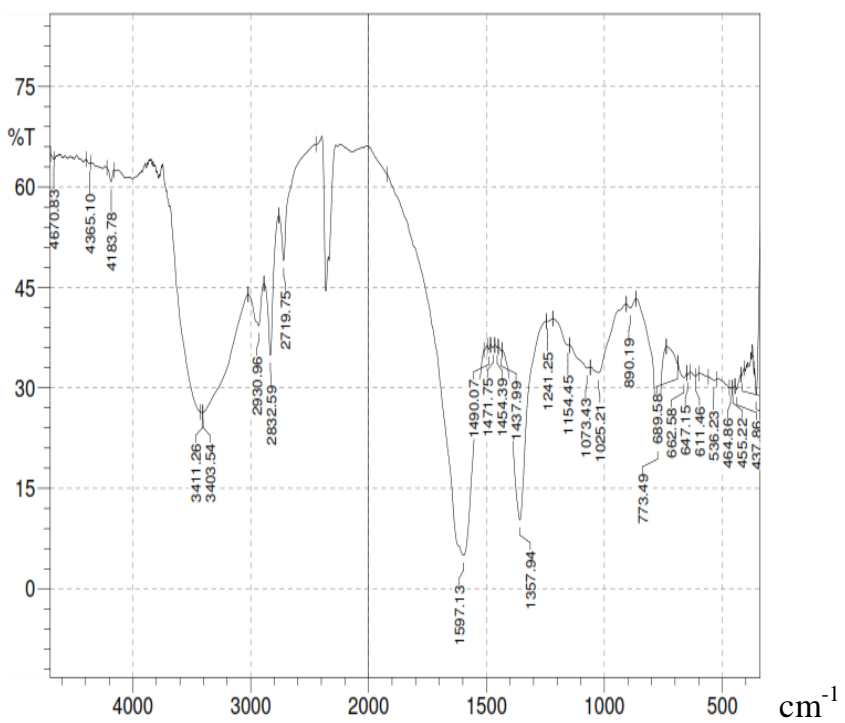

(4)

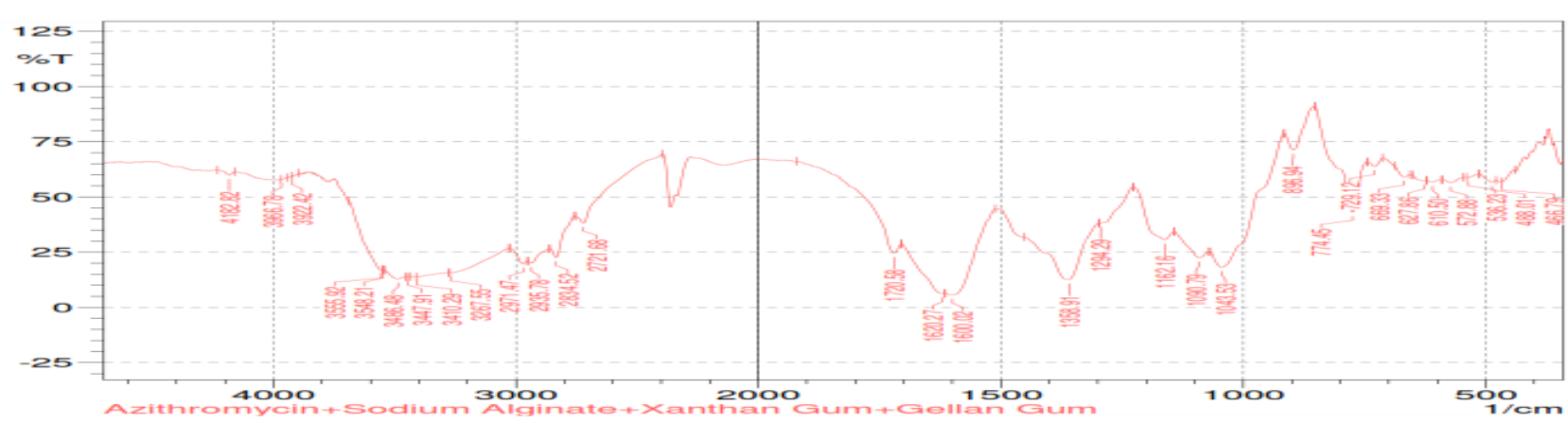

(5)

Figure 1: FTIR compatibility studies: (1) Azithromycin dihydrate (2) sodium alginate (3) xanthan gum (4) gellan gum (5) drug + polymers 
There were almost no change in the peak regions of pure drug like aromatic primary amine group stretch at $3494 \mathrm{~cm}^{-1}$, Methyl $-\mathrm{CH}$ symmetric stretch at $2973 \mathrm{~cm}^{-1}$ and $-\mathrm{C}=\mathrm{O}$ stretch at $1718 \mathrm{~cm}^{-1}$, when compared with the mixture of drug and polymer ${ }^{16}$.
The concentration of polymers used affect the viscosity as well as gelling capacity. As the concentration of the gelling polymers were increased the viscosity of the formulation also increased with an increase in the gelling capacity ${ }^{18}$ as shown in table 2 .

Table 2: Viscosity, Floating time, Floating lag time and Gelling capacity of Azithromycin dihydrate in situ gel formulations

\begin{tabular}{|c|c|c|c|c|c|}
\hline Formulation & $\begin{array}{c}\text { Viscosity of sol } \\
\text { (cps) }\end{array}$ & $\begin{array}{c}\text { Viscosity of } \\
\text { gel (cps) }\end{array}$ & $\begin{array}{c}\text { In vitro floating } \\
\text { lag time (min) }\end{array}$ & $\begin{array}{c}\text { In vitro floating } \\
\text { time (h) }\end{array}$ & $\begin{array}{c}\text { Gelling } \\
\text { capacity }\end{array}$ \\
\hline F1 & 3.5 & 80.6 & $<1$ & $>24$ & + \\
\hline F2 & 5.7 & 84.8 & $<1$ & $>24$ & ++ \\
\hline F3 & 8.2 & 91.1 & $<1$ & $>24$ & +++ \\
\hline F4 & 4.9 & 85.2 & $<1$ & $>24$ & ++ \\
\hline F5 & 8.9 & 93.3 & $<1$ & $>24$ & +++ \\
\hline F6 & 11.6 & 98.1 & $<1$ & $>24$ & +++ \\
\hline F7 & 8.3 & 91.2 & $<1$ & $>24$ & ++ \\
\hline F8 & 8.7 & 91.4 & $<1$ & $>24$ & +++ \\
\hline
\end{tabular}

The amount of drug present in all formulations was evaluated by spectrophotometrically at $215 \mathrm{~nm}$. The results are tabulated in table 3 . The drug content ranges from $97.92 \%$ to $99.27 \%$.

The water uptake by gel was directly proportional to the polymer concentration. As the concentration of the gelling polymers was increased the water uptake by the gel also increased. The $\%$ of water uptake by gel also influenced the drug release from the gel. As the of water uptake by gel increased the drug release was found to decrease $^{17}$. The $\%$ of water uptake by gel is graphically shown in fig 2.
Table 3: Drug content of Azithromycin dihydrate in situ gels in $0.1 \mathrm{~N} \mathrm{HCl}$

\begin{tabular}{|c|c|}
\hline Formulations & Drug Content (\%) \\
\hline F1 & 98.52 \\
\hline F2 & 98.84 \\
\hline F3 & 99.16 \\
\hline F4 & 98.76 \\
\hline F5 & 98.85 \\
\hline F6 & 99.27 \\
\hline F7 & 97.29 \\
\hline F8 & 97.99 \\
\hline F9 & 99.09 \\
\hline
\end{tabular}

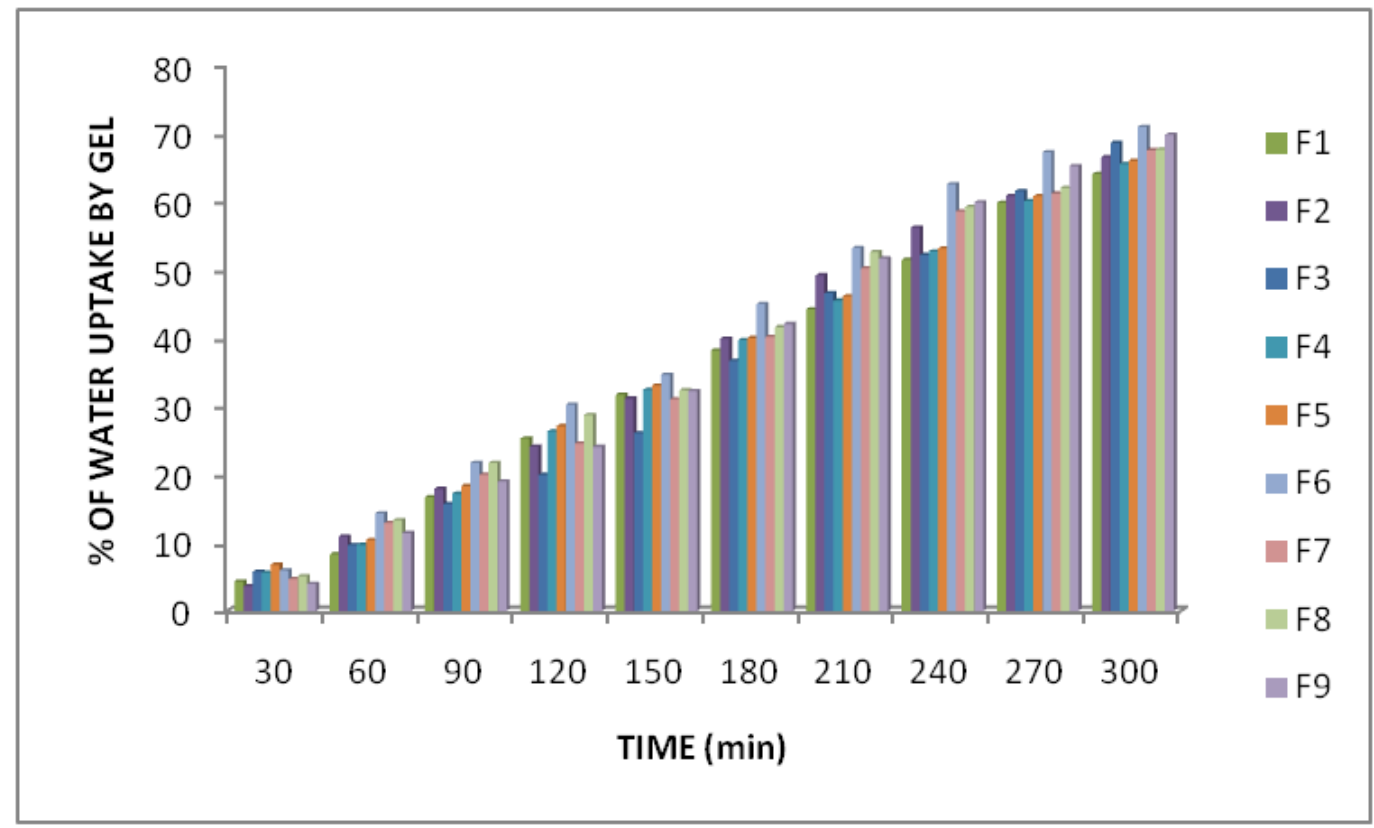

Figure 2: \% of water uptake by Azithromycin dihydrate in situ gel formulations (F1-F9) 
For the microbial studies E.coli, Klebsiella, Streptococcus was selected. H. pylori were not used as a reference micro organism because they are difficult to work with, make larger zone of inhibition which may overlap and they usually die readily. The effect was studied by comparing the zone of inhibition of the microbial growth as tabulated in table 4. The oral floating in situ gelling system of Azithromycin dihydrate was found to be effective in eradication of bacteria causing stomach infection ${ }^{16}$.

Table 4: Microbial studies of various formulations of Azithromycin dihydrate floating in situ gels

\begin{tabular}{|c|c|c|c|}
\hline \multirow{2}{*}{ Formulations } & \multicolumn{3}{|c|}{ Zone of inhibition (cm) } \\
\cline { 2 - 4 } & E.coli & Klebsiella & Streptococcus \\
\hline Standard drug & 1.73 & 1.79 & 1.59 \\
\hline F1 & 1.70 & 1.64 & 1.25 \\
\hline F2 & 1.68 & 1.65 & 1.30 \\
\hline F3 & 1.66 & 1.69 & 1.40 \\
\hline F4 & 1.65 & 1.71 & 1.39 \\
\hline F5 & 1.70 & 1.67 & 1.38 \\
\hline F6 & 1.69 & 1.65 & 1.37 \\
\hline F7 & 1.63 & 1.69 & 1.39 \\
\hline F8 & 1.61 & 1.66 & 1.41 \\
\hline F9 & 1.60 & 1.69 & 1.36 \\
\hline
\end{tabular}

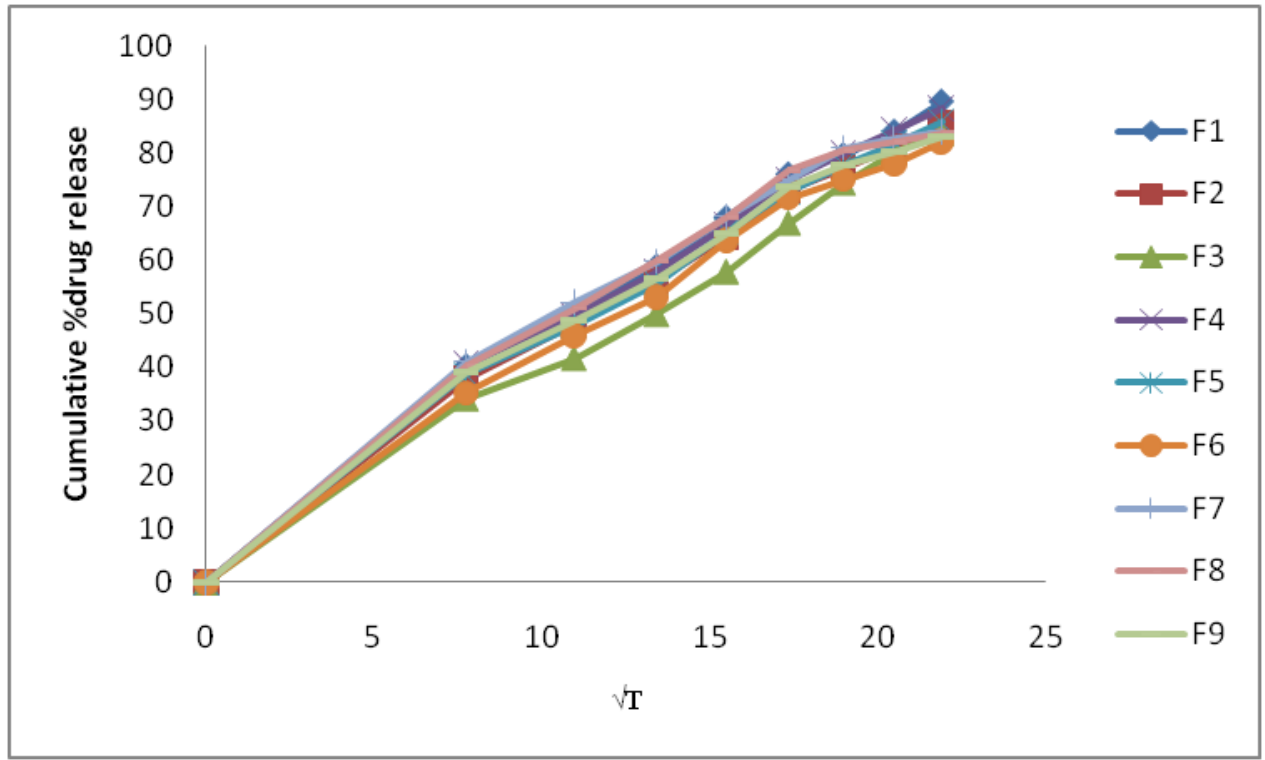

Figure 4: Higuchi plot of Azithromycin dihydrate in situ gels formulations (F1-F9)

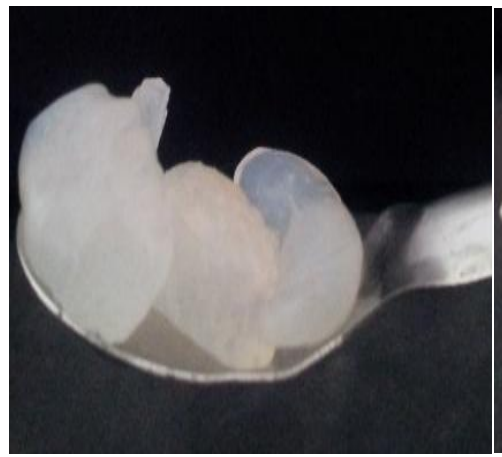

A

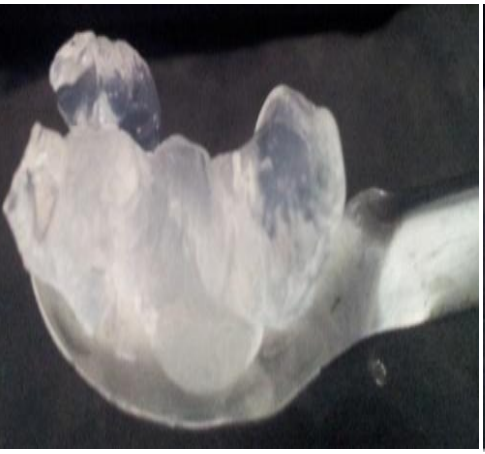

B

C

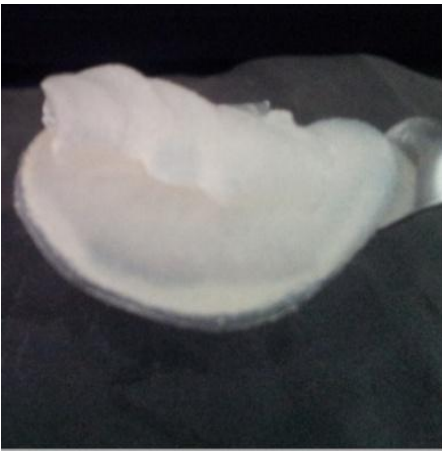

Figure 5: Photograph of formed Azithromycin dihydrate in situ gel formulations: A (F3), B (F6), C (F9) 
The concentration of gelling polymers on in vitro drug release from floating in situ gels is showed in fig 3. A significant decrease in rate and extent of drug release is seen with increase in polymer concentration this pattern is attributed to increase in the density of the polymer matrix and also an increase in the diffusional path length which the drug molecules have to travel. With the increase in the concentration of gelling polymer decreased rate and extent of drug release with sustained effect was observed table 5 and fig 3 . The release of drug from these gels was characterized by an initial phase of high release which is actually the burst effect ${ }^{18}$.

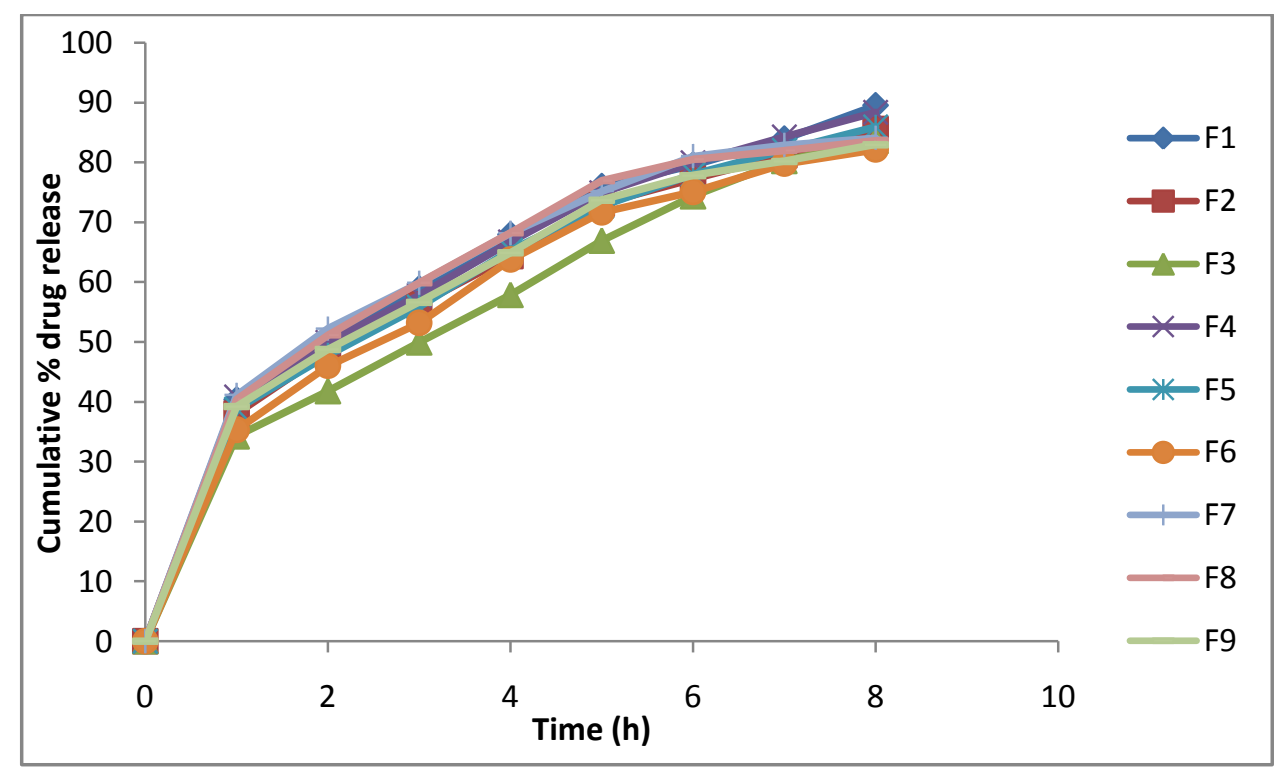

Fig 3: In vitro drug release of Azithromycin dihydrate in situ gel from different gelling polymers in different concentrations

Table 5: In vitro cumulative \%drug release of Azithromycin dihydrate in situ gel

\begin{tabular}{|c|c|c|c|c|c|c|c|c|c|}
\hline \multirow{2}{*}{$\begin{array}{c}\text { Time } \\
(\mathbf{h})\end{array}$} & \multicolumn{9}{|c|}{ Cumulative \%drug release } \\
\cline { 2 - 11 } & F1 & F2 & F3 & F4 & F5 & F6 & F7 & F8 & F9 \\
\hline 0 & 0 & 0 & 0 & 0 & 0 & 0 & 0 & 0 & 0 \\
\hline 1 & 40.34 & 38.02 & 34.22 & 40.79 & 38.78 & 35.32 & 41.11 & 40.40 & 39.21 \\
\hline 2 & 50.12 & 48.32 & 41.77 & 49.91 & 47.79 & 45.98 & 52.21 & 51.12 & 48.75 \\
\hline 3 & 58.88 & 56.21 & 49.91 & 57.82 & 55.81 & 53.16 & 59.85 & 59.88 & 56.63 \\
\hline 4 & 67.91 & 64.32 & 57.85 & 66.73 & 65.33 & 63.75 & 68.16 & 68.19 & 64.89 \\
\hline 5 & 75.99 & 73.10 & 66.91 & 74.90 & 72.69 & 71.64 & 75.13 & 76.90 & 73.70 \\
\hline 6 & 79.56 & 77.21 & 74.32 & 79.93 & 77.97 & 75.06 & 81.01 & 80.50 & 77.80 \\
\hline 7 & 83.92 & 81.15 & 80.22 & 84.22 & 81.99 & 79.77 & 82.89 & 81.97 & 80.16 \\
\hline 8 & 89.49 & 85.54 & 83.59 & 88.36 & 85.92 & 82.11 & 84.06 & 83.61 & 82.96 \\
\hline
\end{tabular}

In vitro drug release study for all nine prepared formulations showed sustained drug release for longer period of time and followed Higuchi release pattern ${ }^{16}$ as tabulated in table 6 .

Table 6: Release mechanism of Azithromycin dihydrate floating in situ gels

\begin{tabular}{|c|c|c|c|c|}
\hline Formulations & $\begin{array}{c}\text { Zero Order } \\
\left(\mathbf{R}^{\mathbf{2}} \text { value) }\right.\end{array}$ & $\begin{array}{c}\text { First Order } \\
\left(\mathbf{R}^{\mathbf{2}} \text { value) }\right.\end{array}$ & $\begin{array}{c}\text { Higuchi Model } \\
\left(\mathbf{R}^{\mathbf{2}} \text { value }\right)\end{array}$ & $\begin{array}{c}\text { Peppas model } \\
\text { (n values) }\end{array}$ \\
\hline F1 & 0.853 & 0.979 & 0.989 & 0.656 \\
\hline F2 & 0.910 & 0.986 & 0.990 & 0.660 \\
\hline F3 & 0.811 & 0.987 & 0.995 & 0.660 \\
\hline F4 & 0.855 & 0.988 & 0.988 & 0.655 \\
\hline F5 & 0.861 & 0.987 & 0.990 & 0.658 \\
\hline F6 & 0.865 & 0.987 & 0.988 & 0.659 \\
\hline F6 & 0.813 & 0.986 & 0.975 & 0.661 \\
\hline F9 & 0.811 & 0.988 & 0.974 & 0.660 \\
\hline
\end{tabular}




\section{CONCLUSION:}

On the basis of obtained results and experimental conditions used in the study, F6 formulation showed sustained release of drug from the gel. The developed formulations met all prerequisites to become an in situ gelling floating system, formed and floated instantaneously in the $\mathrm{pH}$ conditions of the stomach. This study demonstrated that in situ gels formed by oral administration of solutions of gellan gum and releases Azithromycin dihydrate in a sustained manner over a period of time for at least $8 \mathrm{~h}$. It was observed that the feasibility of in vitro gel was formed form aqueous solutions of different gelling polymers. It can be concluded from the study that, increase in concentration of different gelling polymers decreases the release of drug from the prepared formulations. Thus, it can be

\section{REFERENCES}

1. Marshall BJ, Warren JR. Unidentified curved bacilli in the stomach of patients with gastritis and peptic ulceration. Lancet. 1984;1:1311-15.

2. Shah S, Qaqish R, Patel V Amiji M. Evaluation of the factors influencing stomach specific delivery of antibacterial agents for Helicobacter pylori infection. J. Pharm. Pharmacol. 1999;51:667-72.

3. Yokel RA, Dickey KM, Goldberg AH. Selective adherence of a sucralfate tetracycline complex to gastric ulcers: implications for the treatment of Helicobacter pylori. Biopharm. Drug Dispos. 1995;16:475-79.

4. Sungthingjeen $\mathrm{S}$, Paeratakul O, Limmatvapirat S, Puttipupathachorn S. Preparation and invitro evaluation of multiple units floating drug delivery system based on gas formation technique. Int J Pharm. 2..6;324:136-43.

5. Sarasuja S, Shyamala B. Nasal Drug Delivery: An overview. Indian J Pharm Sci. 2005;67(1):19-25.

6. Peppas NA, Bures P, Leobandung W. Ichikawa $H$. Hydorogels in pharmaceuticals formulations. Eur $\mathrm{J}$ Pharm Biopharm. 2000;50(1):27-46.

7. Chambers HF. Protein synthesis inhibitors and miscellaneous anti bacterial agents: maxrolides. In: Bruton LL, Lazo JS, Parker KL, editors. Goodman and Gilman's: the pharmacological basis of therapeutics. $11^{\text {th }}$ ed. United States of America: McGraw-Hill Companies Inc, 2006;4:1182-87.

8. Yoshiaki Yuguchi, Thanh Thi Thu Thuy, Hiroshi U, Kamji K. Structural characterization of carrageenan gels, temperature concluded that the release of Azithromycin dihydrate could be targeted to stomach and sustain the drug release over a period of time. Further investigation is needed to prepare the best and most successful formulation of Azithromycin dihydrate in situ gelling system.

\section{ACKNOWLEDGEMENTS:}

The authors are thankful to the Management, Luqman College of Pharmacy, Gulbarga, Karnataka for providing all the necessary facilities to carry out this research work.

\section{DECLARATION OF INTERERST:}

Authors show no conflict of interest.

and concentration dependence. Food hydorcolloids. 2002;13(6): 515-522.

9. http://www.fao.org/docrep/w6355e/w6355e0x.htm\#TopOfPa ge

10. http://www.sciencelab.com/msds.php?msdsId=9924955

11. US Pharmacopoeia 27, 2004.First Supplement. US Pharmacopoeial Convention, Rockville, MD, pp. 732-33.

12. Parekh HB, Jivani R, Jivani NP, PatelLD, Ami M, Krunal S. Novel in situ polymeric drug delivery system: a review. J Drug Deliv Thera. 2012;2(5):136-45.

13. Rajalakshmi R et al. Development and evaluation of a novel floating in situ gelling system of Levofloxacin Hemihydrate. Int J Innovative Pharm Res. 2011;2(1):102-08.

14. http://www.sciencelab.com/msds.php?msdsId=9924955

15. Kubo W, Miyazaki S, Attwood D. Oral sustained delivery of paracetamol from in situ gelling gellan and sodium alginate formulations. Int J Pharm. 2003;258(1-2):55-64.

16. Rajalakshmi R et al. Development and evaluation of a novel floating in situ gelling system of Azithromycin dihydrate dihydrate. Indo American J Pharm Res. 2013;3(4).

17. Panwar P, Chourasiya D, Jain G, Sheorey RV. Formulation and evaluation of oral floatable in situ gel of diltiazem $\mathrm{HCl}$. Int. J. Novel Drug Deliv. Tech. 2012;2(1):264-70.

18. Rajalakshmi R. et al. Development and evaluation of a novel floating in situ gelling system of levofloxacin hemihydrate. Interanational Journal of Innovative Pharmaceutical Research. 2011;2(1):102-108. 